Article

\title{
Properties of flame-powder sprayed aluminum coatings reinforced with particles of carbonaceous materials
}

\author{
Artur Czupryński ${ }^{1, *}$ \\ 1 Silesian University of Technology, Poland; \\ * Correspondence: Dr. Artur Czupryński; artur.czuprynski@polsl.pl
}

Received: 07.03.2019; Accepted: 18.04.2019

\begin{abstract}
The article presents the results of research on tribological properties of aluminum coatings, reinforced with particles of carbon nanotubes Nanocyl NC 7000 in quantities of 0.5 wt.\% and 1 wt.\% as well as carburite (elemental carbon) in an amount of $0.5 \mathrm{wt} . \%$, flame-powder sprayed on a non-alloy structural steel grade S235J0 according to EN 10027-1.The coating properties were assessed based on macro and microscopic metallographic examinations, chemical composition tests, microhardness measurements and abrasion and erosive wear resistance tests. The obtained results were compared with the results obtained for samples with coatings made of aluminum powder - EN AW 1000 series.
\end{abstract}

Key words: flame-powder spraying; coatings; aluminum; carbon nanotubes; carburite; abrasion resistance; resistance to erosive wear

\section{Introduction}

Modern civilization expects from scientists involved in materials engineering to manufacture light and durable materials that meet high strength and quality requirements set for innovative constructions

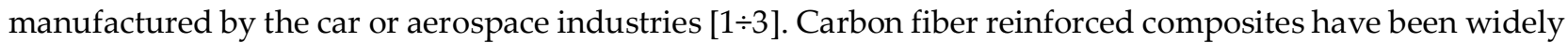
used in the production of aircraft brakes, space constructions, military and commercial aircraft, lithium-ion batteries and sports equipment. The nanotechnology has had a strong influence on the direction of research in the area of surface engineering and related technologies of making surface layers and coatings [4:11]. Nowadays, it is possible to perform not only conventional tribological coatings with specific frictional characteristics (high or low coefficient of friction) and resistance to abrasive wear, erosion or corrosion, but also coatings of unprecedented properties, often intended for special applications and working in difficult conditions, i.e. nanocomposite coatings with high hardness and high resistance to dynamic loads, coatings with frictional characteristics which can adapt to changing operating conditions (temperature, humidity), nanostructured coatings with a thermal barrier (Thermal Barrier Coatings) or biocompatible coatings [12,13]. Pioneers in the field of thermal spraying processes of composite coatings of aluminumcarbon nanotubes (CNT) was a research group from Florida International University, which successfully deposited carbon nanotubes (CNTs) in the Al-Si matrix in the powder plasma spraying process [14]. In the literature, however, there are no data regarding tribological properties of powder flame sprayed (PFS) aluminum coatings reinforced with carbon nanotubes (CNT). The purpose of this article is to present the state of knowledge in this area of research activity and to present the possibility of using powder flame spraying (PFS) technology for the production of composite coatings with a metallic matrix reinforced with carbon nanotubes (CNT).

\section{Materials and methods}

The research aimed at comparing the structure, chemical composition, hardness and resistance to abrasive and erosive wear of aluminum coatings powder-flame sprayed on non-alloy structural steel grade S235J0. The coatings were reinforced with carbon nanotube nanocyl NC 7000 particles in the amount of 0.5 $\mathrm{wt} . \%$ and $1 \mathrm{wt} . \%$ and the carburite in the amount of $0.5 \mathrm{wt} . \%$ with a reference coating made of aluminum powder of EN AW 1000 series. Carburite as a reinforcement of the aluminum matrix was used to have the possibility to compare the tribological properties of the composite coating thus produced with the composite coating with aluminum matrix reinforced with carbon nanotubes (CNT), with the equal weight fraction of the carbon material. The additive material for powder flame spraying was obtained by mixing in appropriate proportions of aluminum powder of EN AW 1000 series (Table I) with carbon nanotubes 
of the Nanocyl NC 7000 series (Table II) and aluminum powder with carburite (elemental carbon) in the form of a coal dust (Table III).

Table I. Aluminum powder specification, EN AW 1000 series

\begin{tabular}{cccc}
\hline Specification & UM & Guaranteed parameters & Research results \\
\hline Aluminum content $(\mathrm{Al})$ & $\%$ & $\min 99.7$ & 99.7 \\
Iron content $(\mathrm{Fe})$ & $\%$ & $\max 0.2$ & 0.2 \\
Silicon content $(\mathrm{Si})$ & $\%$ & $\max 0.12$ & 0.12 \\
Copper content $(\mathrm{Cu})$ & $\%$ & $\max 0.004$ & 0.004 \\
Moisture & $\%$ & $\max 0.1$ & 0.1 \\
Bulk density & $\mathrm{g} / \mathrm{dm}^{3}$ & $\min 1000$ & 1050 \\
Granulation above $0,045 \mathrm{~mm}$ & $\%$ & $85.0 \div 100.0$ & 98.0 \\
Granulation above $0,1 \mathrm{~mm}$ & $\%$ & $5.0 \div 30.0$ & 15.3 \\
Granulation above $0,16 \mathrm{~mm}$ & $\%$ & $\max 5.0$ & 0.0 \\
Granulation below $0,045 \mathrm{~mm}$ & $\%$ & - & 2.0 \\
\hline
\end{tabular}

Table II. Structure and specification of Nanocyl NC 7000 carbon nanotubes

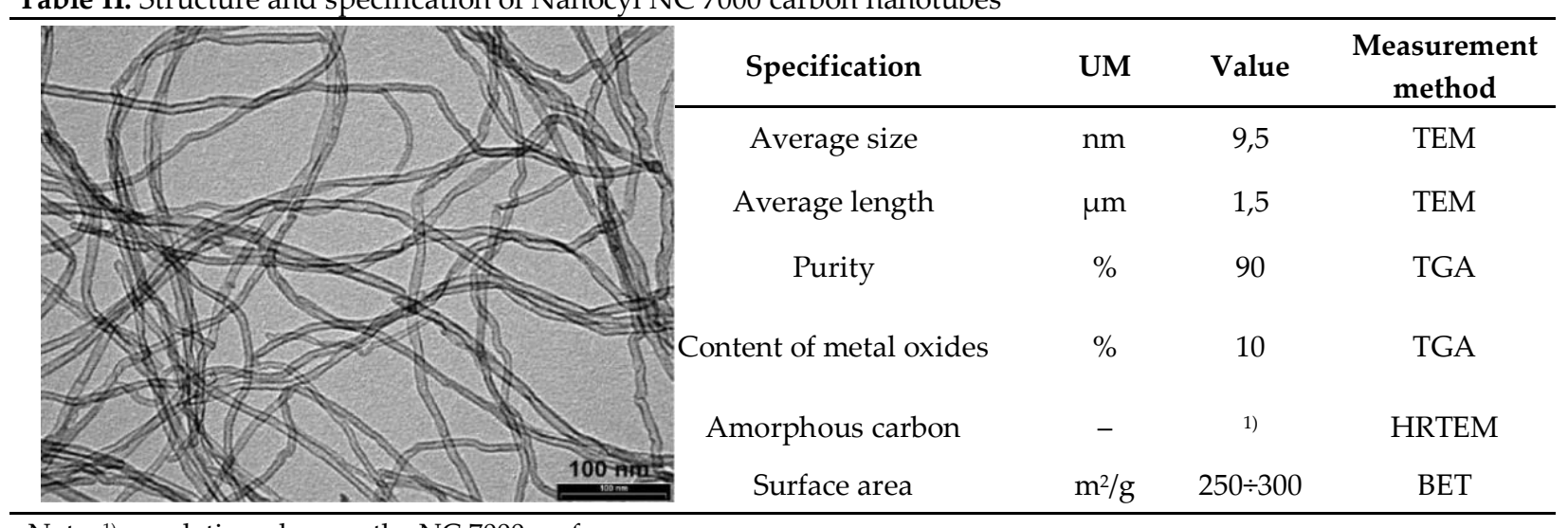

Note: ${ }^{1)}$ pyrolytic carbon on the NC 7000 surface

Table III. Structure and specification of carburite in the form of a coal dust

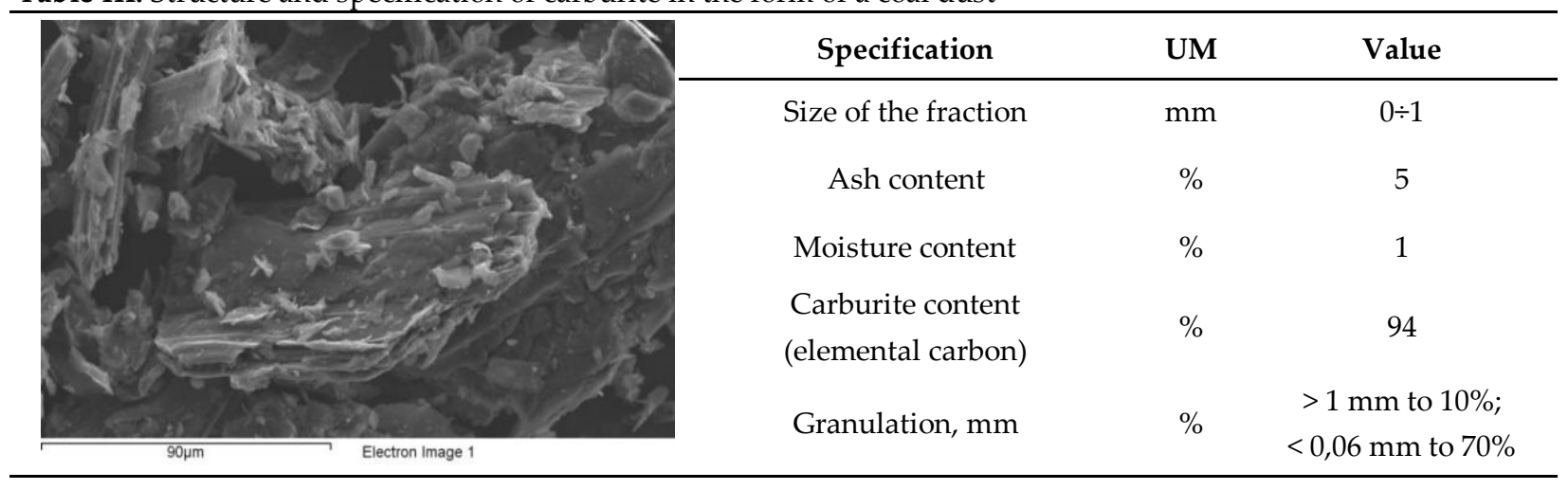

The spraying process was carried out on a production stand equipped with a modern modular oxygenacetylene system CastoDyn DS 8000 for manual powder flame spraying. Steel plates with the dimensions of $150 \times 150 \times 5 \mathrm{~mm}$, before the spraying process, were subjected to abrasive blasting and were preheated with a gas burner to a temperature of approx. $40^{\circ} \mathrm{C}$. The burner was guided in a wall position covering the whole surface of the sheet, and then the spraying direction was changed several times by 90 degrees, until a coating with a thickness of approx. $1.0 \mathrm{~mm}$ was obtained (Fig. 1b).

The criterion for visual evaluation of the quality of sprayed coatings was to make the surface layers have an appropriate thickness, good adhesion to the substrate, continuity, uniformity of coverage and low porosity (ISO 14923: 2005). Optimal parameters of powder flame spraying of aluminum coating and aluminum coatings reinforced with particles of carbon materials, determined on the basis of preliminary technological tests are presented in Table IV. The view of test panels with flame-sprayed coatings on the aluminum matrix is shown in Figure 2. 


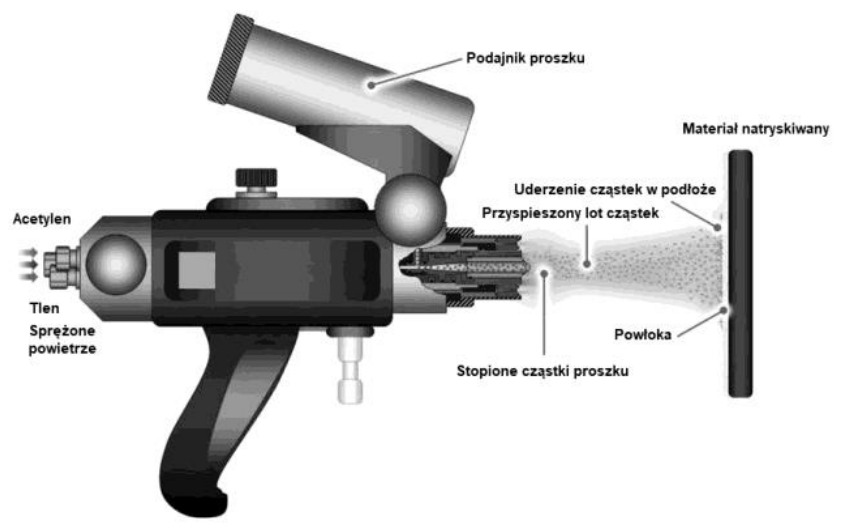

(a)

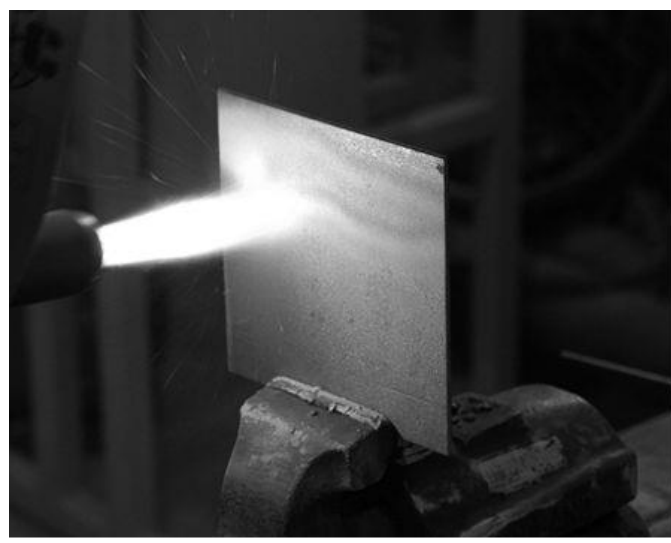

(b)

Fig. 1. Powder flame spraying process: a) scheme of a manual burner for flame powder spraying [15], b) photo from the trial of manual flame powder spraying of an aluminum coating with CastoDyn DS 8000 burner
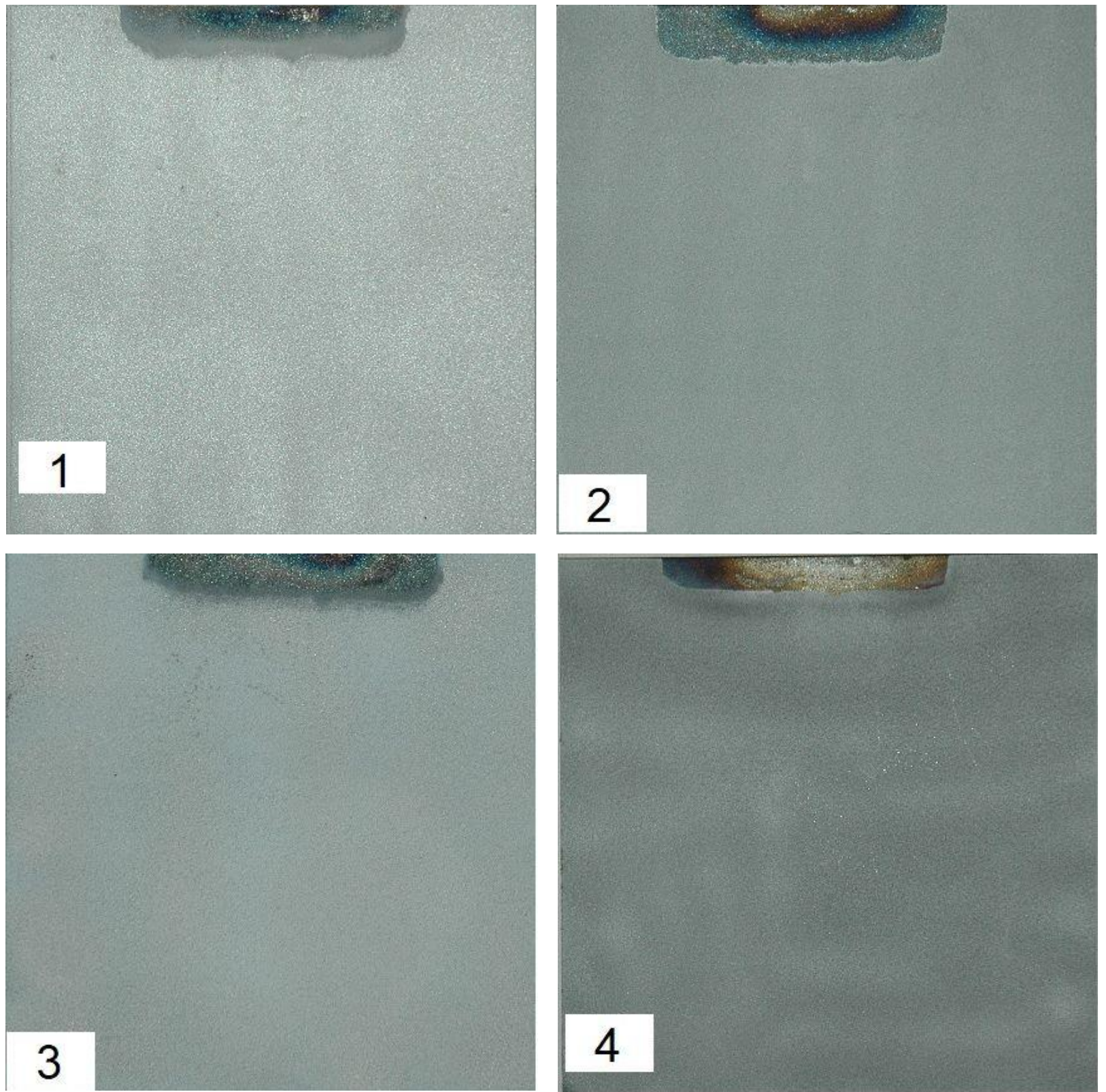

Fig. 2. View of test panels with flame-sprayed coatings on the aluminum matrix: 1) EN AW 1000 aluminum powder; 2) EN AW 1000 aluminum powder with the addition of $0.5 \mathrm{wt}$ \% Nanocyl NC 7000 carbon nanotubes; 3) EN AW 1000 aluminum powder with the addition of 1 wt.\% Nanocyl NC 7000 carbon nanotubes; 4) EN AW 1000 aluminum powder with the addition of 1 wt.\% carburite (elemental carbon) 
Table IV. Parameters of manual flame powder spraying of aluminum coatings and coatings on aluminum matrix reinforced with particles of carbonaceous materials

\begin{tabular}{cccccccc}
\hline $\begin{array}{c}\text { Sample } \\
\text { number }\end{array}$ & Type of powder & $\begin{array}{c}\text { Oxygen } \\
\text { working } \\
\text { pressure, } \\
\text { bar }\end{array}$ & $\begin{array}{c}\text { Acetylene } \\
\text { working } \\
\text { pressure, } \\
\text { bar }\end{array}$ & $\begin{array}{c}\text { Air } \\
\text { working } \\
\text { pressure, } \\
\text { bar }\end{array}$ & $\begin{array}{c}\text { Number of } \\
\text { the powder } \\
\text { feeding } \\
\text { orifice }\end{array}$ & $\begin{array}{c}\text { Weight } \\
\text { of the used } \\
\text { powder, } \\
\text { g }\end{array}$ & $\begin{array}{c}\text { Powder } \\
\text { yield, } \\
\text { \% }\end{array}$ \\
\hline 1 & $\mathrm{Al}$ & 4 & 0.7 & 3 & 2 & 93.5 & 60.3 \\
2 & $\mathrm{Al}+0,5 \% \mathrm{CNT}^{1)}$ & 4 & 0.7 & 3 & 2 & 97.0 & 56.2 \\
3 & $\mathrm{Al}+1 \% \mathrm{CNT}^{2}$ & 4 & 0.7 & 3 & 2 & 100.8 & 57.0 \\
4 & $\mathrm{Al}+0,5 \% \mathrm{C}^{2)}$ & 4 & 0.7 & 3 & 2 & 99.7 & 59.4 \\
\hline
\end{tabular}

Notes: ${ }^{1)} \mathrm{CNT}$ - means carbon nanotubes Nanocyl NC 7000; ${ }^{2)} \mathrm{C}$ - means carburite (elemental carbon).

Standard modular work nozzles regulating the flame outlet with the designation SSM 40 were used.

\section{Visual and metallographic examinations of coatings}

In each case, the entire surface of the sample board has been subjected to visual inspection according to PN-EN ISO 14923, in order to assess the quality and identify any nonconformities in the form of cracks, discontinuities, irregularities, porosity or lack of adhesion of the coating. Macro and microscopic observations were made in accordance with PN-EN ISO 17639 on the cross-section of metallographic specimens cut from the center of the sample plates. Additionally, the analysis of chemical composition in selected

areas of the samples which were flame-sprayed with aluminum powder and aluminum powder with the addition of particles of carbonaceous materials was performed on the scanning microscope.

\section{Measurement of coatings hardness}

The measurement of the hardness of powder flame sprayed coatings was made by the Vickers method HV0.1 according to PN-EN ISO 6507-1. Five measurements were made on the external surface and ten measurements on the cross section of the sprayed layer for each of the tested coatings.

\section{Tests of the coating's resistance to erosive wear}

The erosive wear tests of powder flame sprayed coatings on the aluminum matrix were carried out in accordance with ASTM G76-95 as shown in Figure 3. As the erosion material, aluminum oxide powder $\left(\mathrm{Al}_{2} \mathrm{O}_{3}\right)$ with a particle diameter of $71 \mu \mathrm{m}$ was used. Discharge velocity of the particles was set at $70 \pm 2 \mathrm{~m} / \mathrm{s}$, the erodent's expenditure was $2.0 \pm 0.5 \mathrm{~g} / \mathrm{min}$, and the nozzle distance from the sample surface was $10 \mathrm{~mm}$. The tests were carried out at an angle of incidence of the erodent of $90^{\circ}$ and $30^{\circ}$.

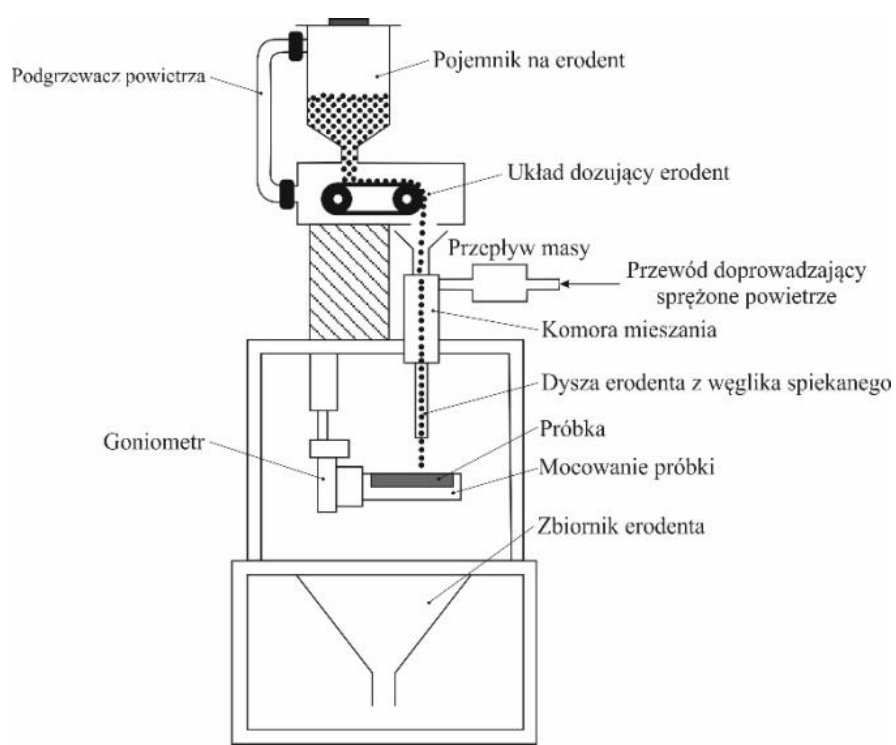

(a)

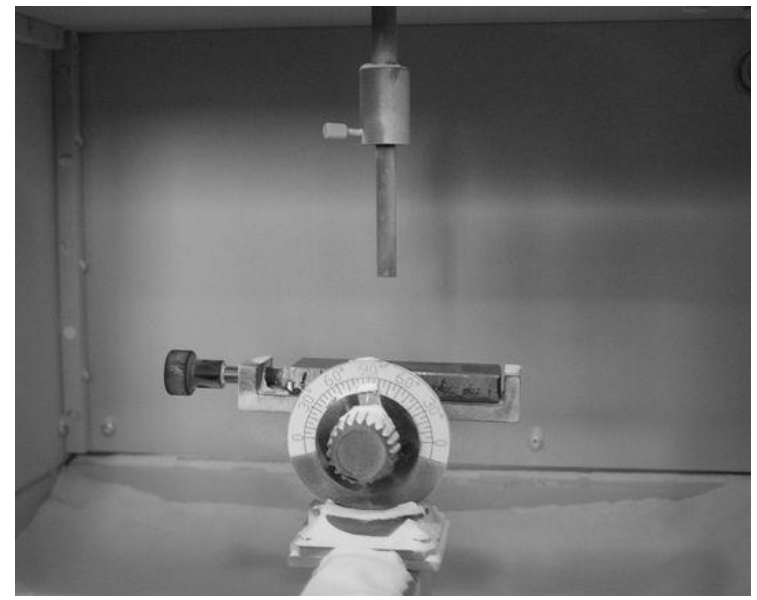

(b)

Fig. 3. Stand for erosion wear resistance tests in accordance with ASTM G76-95: a) general layout of the stand; b) an interior view of the measuring chamber of the blasting device 


\section{Tests of the coating's resistance to abrasive wear}

The tests of resistance to abrasive wear of the metal-mineral type of powder flame sprayed coatings on the aluminum matrix were made according to ASTM G65-00, Procedure E (ASTM G76-95). During the test, the friction wheel made 1000 revolutions, and the abrasive flow rate (A.F.S. Testing Stand 50-70 sand) was $335 \mathrm{~g} / \mathrm{min}$. The test was carried out on the test stand shown in Figure 4.

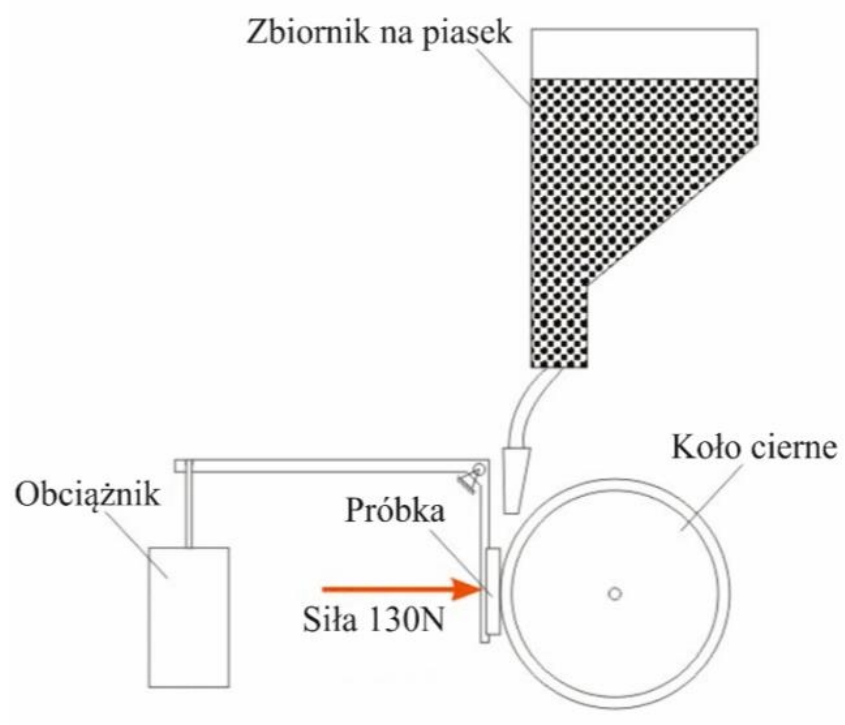

(a)

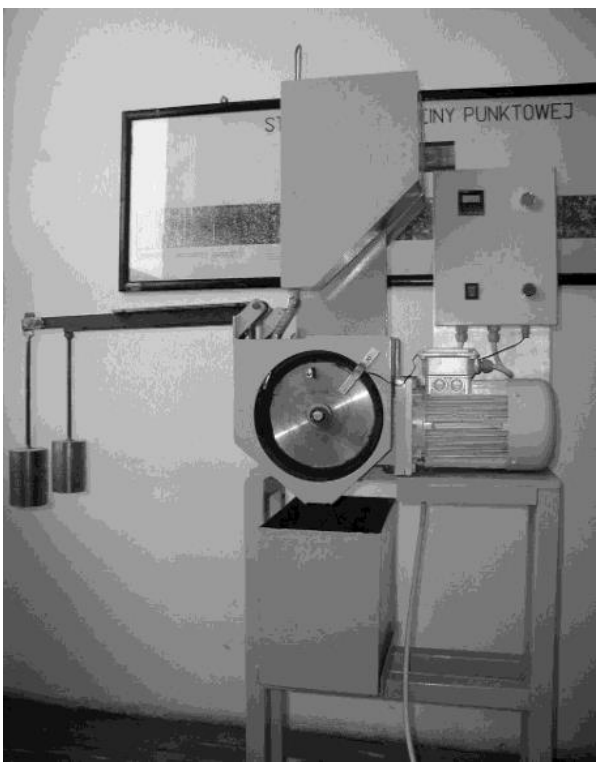

(b)

Fig. 4. Test stand for abrasive wear tests in accordance with ASTM G65-00, Procedure E: a) scheme of the stand; b) general view of the device

\section{Research results}

\section{Results of metallographic examination of coatings}

A view of the metallographic cross-sectional image of individual powder flame sprayed aluminum coatings is shown in Figure 5. The image of the structures obtained by scanning electron microscopy and the SEM report for coatings sprayed with aluminum powder and aluminum powders with the addition of particles of carbon materials are shown in Figures $6 \div 9$.

\section{Hardness measurement}

The measurement of hardness of powder flame sprayed aluminum coatings and coatings on aluminum matrix reinforced with particles of carbonaceous materials was made on the surface at 5 points along one measurement line (Table $\mathrm{V}$ ) and at 10 measuring points on the cross-section of the sample as shown in Figure 10. The results of hardness measurements on the cross-section of coatings flame-sprayed with aluminum powder and powders on aluminum matrix with particles of carbonaceous materials are compared in Figure 11.

Table V. Results of hardness measurements on the surface of coatings flame-sprayed with aluminum powder and powders on aluminum matrix with particles of carbonaceous materials

\begin{tabular}{ccccccccc}
\hline & \multicolumn{7}{c}{ Hardness HV 0.1 } \\
\cline { 2 - 8 } Designation of the sample & \multicolumn{7}{c}{ Measurement point } \\
\cline { 2 - 8 } & $\mathbf{1}$ & $\mathbf{2}$ & $\mathbf{3}$ & $\mathbf{4}$ & $\mathbf{5}$ & Average & $\begin{array}{c}\text { Standard } \\
\text { deviation }\end{array}$ \\
\hline Sample 1 (Al) & 35.2 & 32.5 & 34.8 & 37.2 & 35.1 & 34.96 & 1.67 \\
Sample 2 (Al+0.5\% CNT) & 59.2 & 62.8 & 56.5 & 54.2 & 55.5 & 57.64 & 3.42 \\
Sample 3 (Al+1\% CNT) & 41.2 & 43.2 & 37.5 & 39.2 & 38.7 & 39.96 & 2.25 \\
Sample 4 (Al+0.5\% C) & 30.2 & 27.3 & 28.2 & 27.0 & 28.0 & 28.14 & 1.25 \\
\hline
\end{tabular}


Sample 1 (Al)
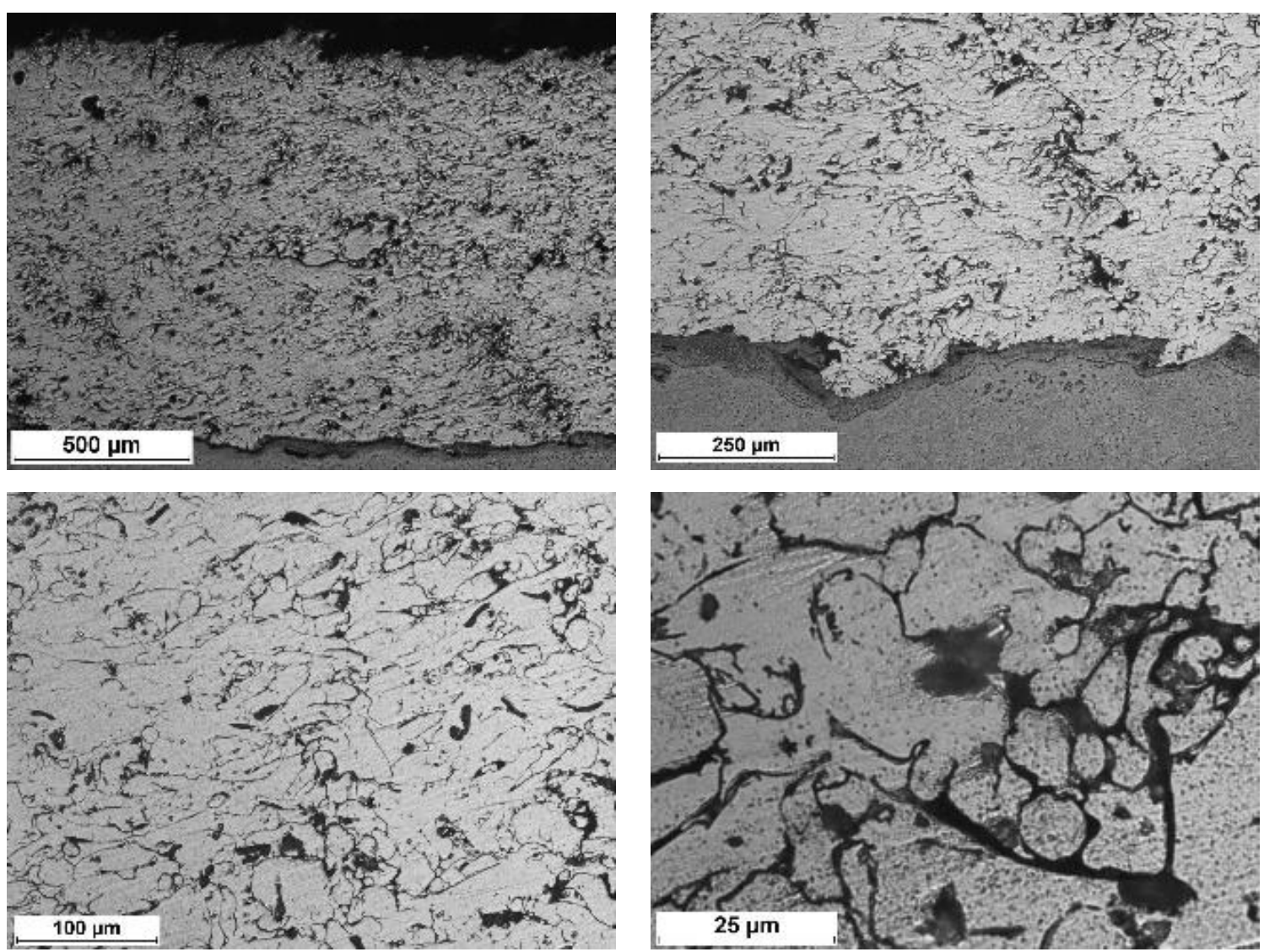

Sample $2(\mathrm{Al}+0,5 \% \mathrm{CNT})$
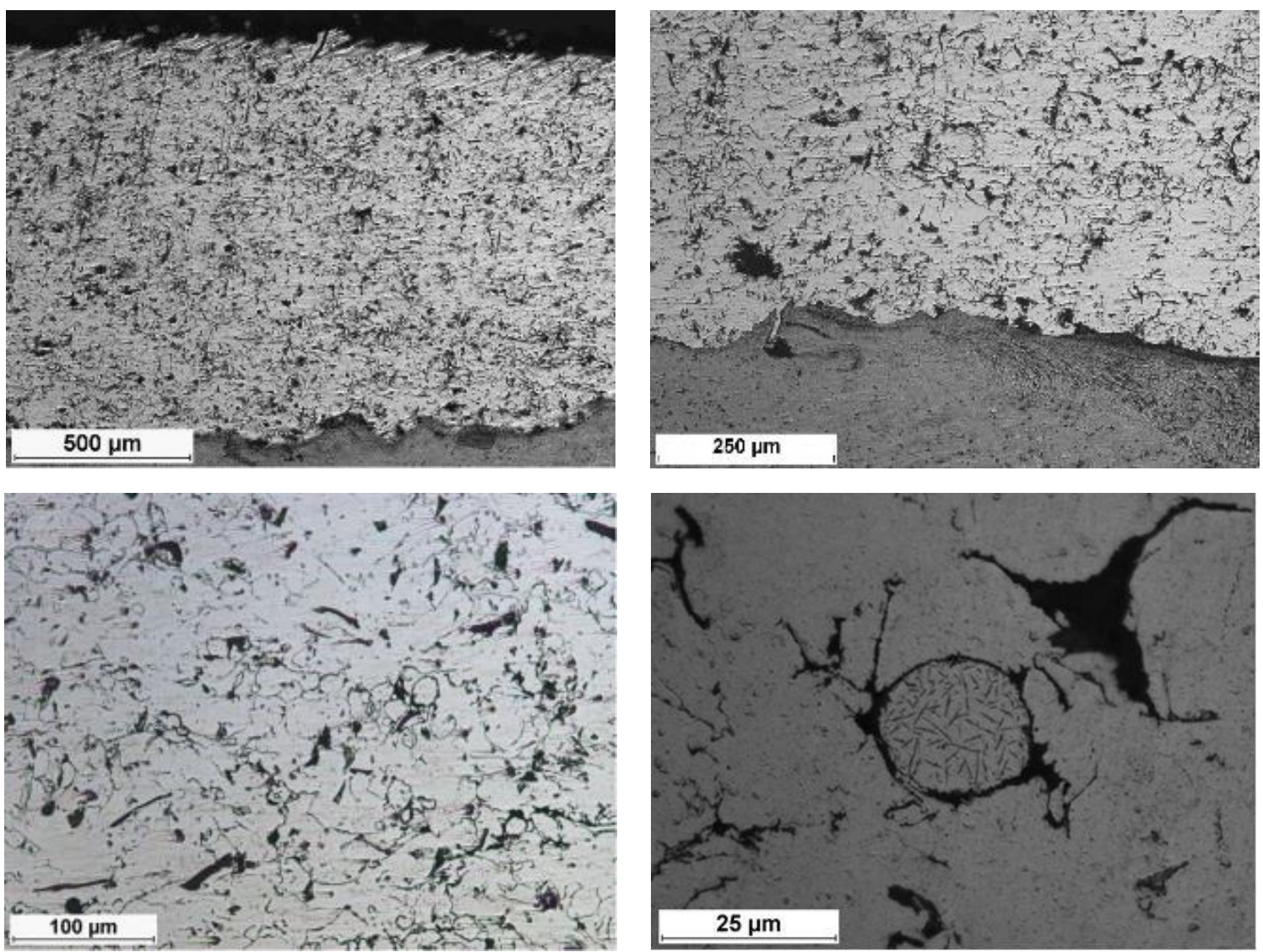

Sample $3(\mathrm{Al}+\mathbf{1} \% \mathrm{CNT})$ 

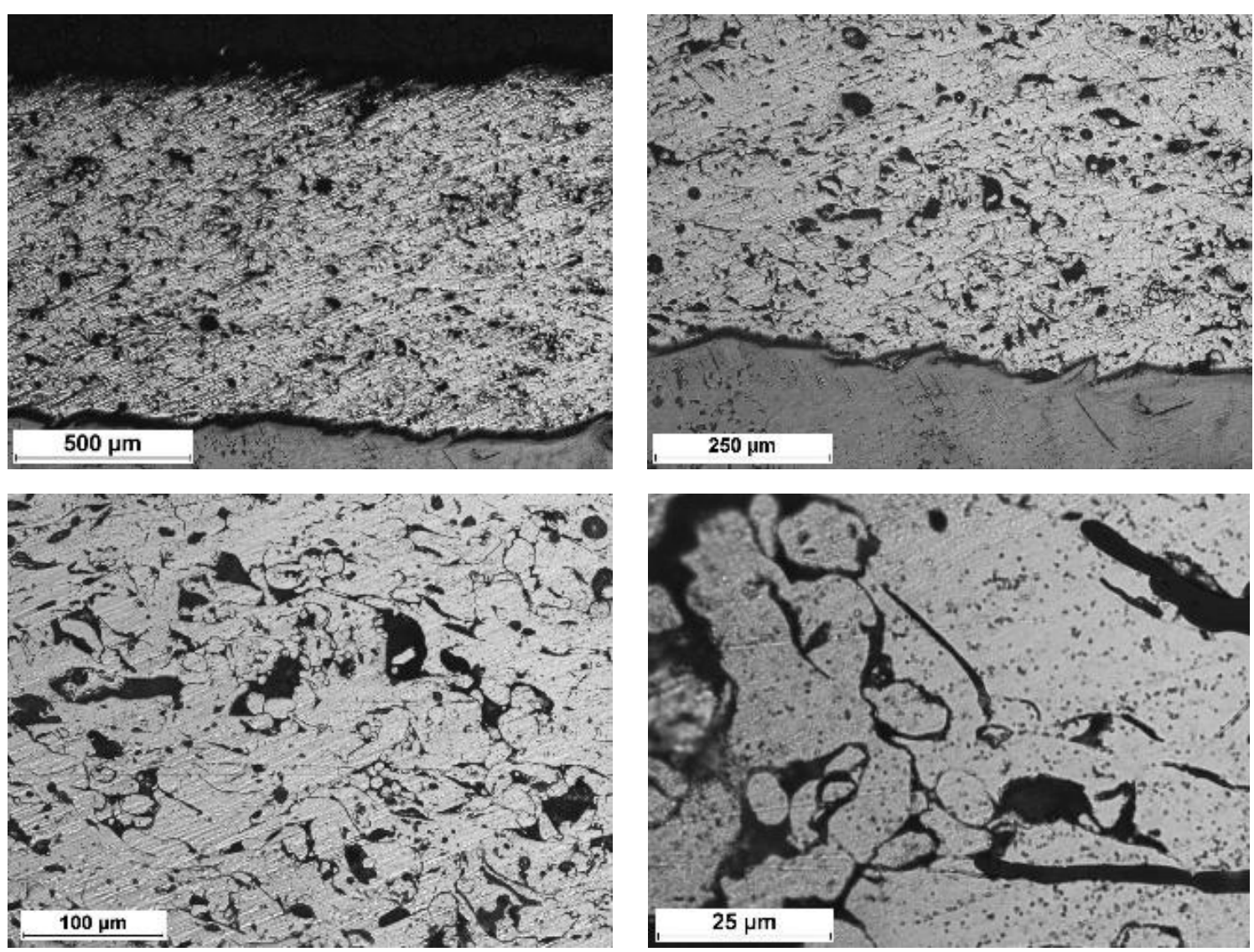

Sample $4(\mathrm{Al}+0,5 \% \mathrm{C})$
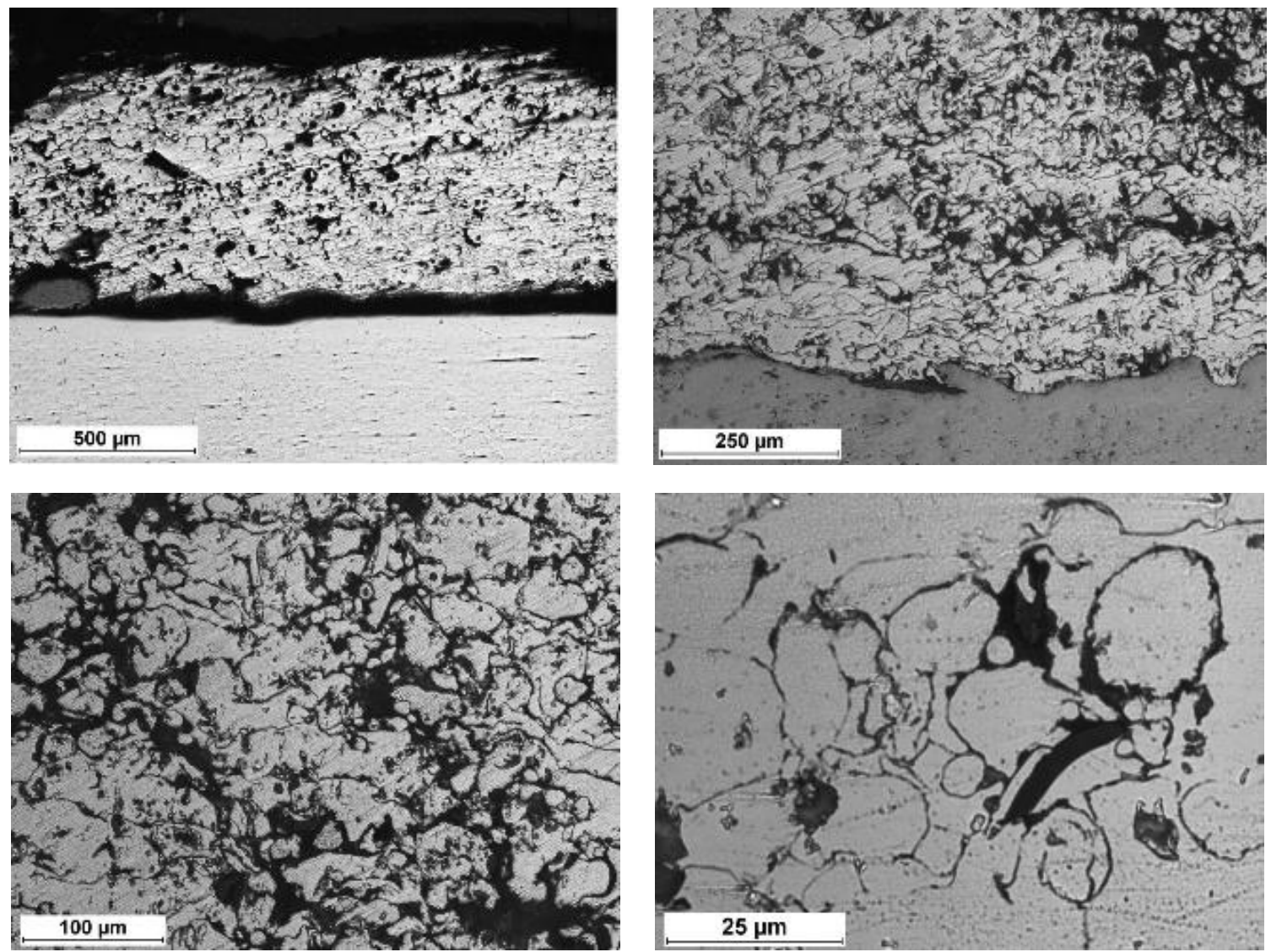

Fig. 5. Macro and microstructure of coatings flame-sprayed with aluminum powder and powders on aluminum matrix with the addition of carbon nanotubes and carburite, digestion: $\mathrm{HCl}+\mathrm{HNO}_{3}$ 


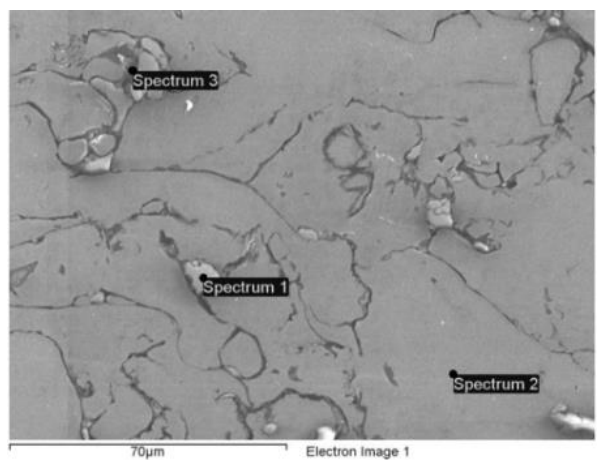

\begin{tabular}{cccc}
\multicolumn{4}{c}{ Sample 1 (Al) } \\
\hline $\begin{array}{c}\text { Designation } \\
\text { of the measurement } \\
\text { area }\end{array}$ & Chemical composition, wt.\% \\
\hline Spectrum 1 & C & O & Al \\
Spectrum 2 & 5.16 & 1.87 & 92.97 \\
Spectrum 3 & 6.09 & 1.41 & 92.51 \\
Standard deviation & 16.05 & 6.75 & 77.20 \\
\hline
\end{tabular}

Fig. 6. Image of the structure of the coating flame-sprayed with an aluminum powder of the EN AW 1000 series along with the selection of areas for which the chemical composition analysis was performed on a scanning electron microscope

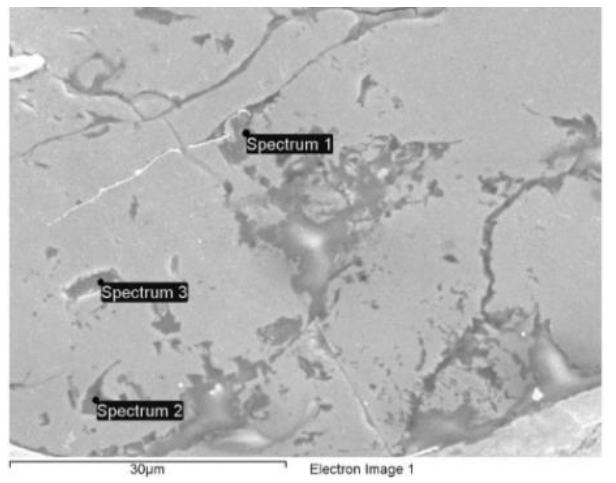

\begin{tabular}{ccc}
\multicolumn{3}{c}{ Sample 2 $(\mathbf{A l + 0 , 5 \%}$ CNT) } \\
\hline $\begin{array}{c}\text { Designation } \\
\text { of the measurement } \\
\text { area }\end{array}$ & \multicolumn{2}{c}{ Chemical composition, } \\
wt. $\%$ & Al \\
\hline Spectrum 1 & 17.03 & 82.97 \\
Spectrum 2 & 20.25 & 79.75 \\
Spectrum 3 & 7.42 & 92.58 \\
Standard deviation & 6.67 & 6.67
\end{tabular}

Fig. 7. Image of the structure of the coating flame-sprayed with aluminum powder with the addition of Nanocyl NC 7000 carbon nanotubes in the amount of $0.5 \mathrm{wt} . \%$ along with the selection of areas for which the chemical composition analysis was performed on a scanning electron microscope

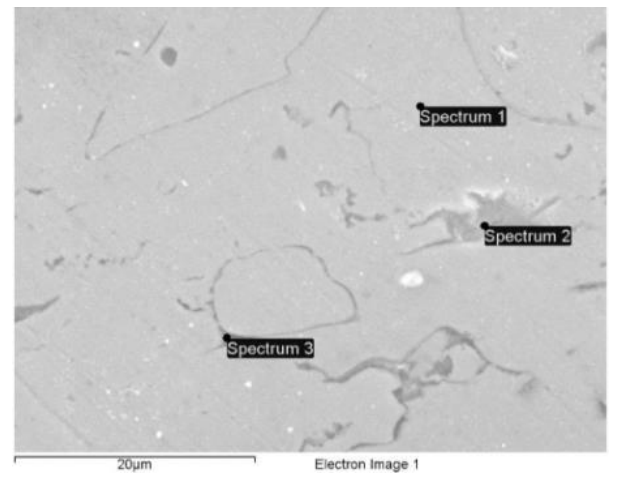

\begin{tabular}{ccc}
\multicolumn{3}{c}{ Sample 3 (Al+1\% CNT) } \\
\hline $\begin{array}{c}\text { Designation } \\
\text { of the measurement } \\
\text { area }\end{array}$ & \multicolumn{2}{c}{ Chemical composition, } \\
wt.\% & Al \\
\hline Spectrum 1 & 6.30 & 93.70 \\
Spectrum 2 & 11.87 & 88.13 \\
Spectrum 3 & 33.05 & 66.95 \\
Standard deviation & 14.11 & 14.11
\end{tabular}

Fig. 8. Image of the structure of the coating flame-sprayed with aluminum powder with the addition of Nanocyl NC 7000 carbon nanotubes in the amount of $1 \mathrm{wt} . \%$ along with the selection of areas for which the chemical composition analysis was performed on a scanning electron microscope

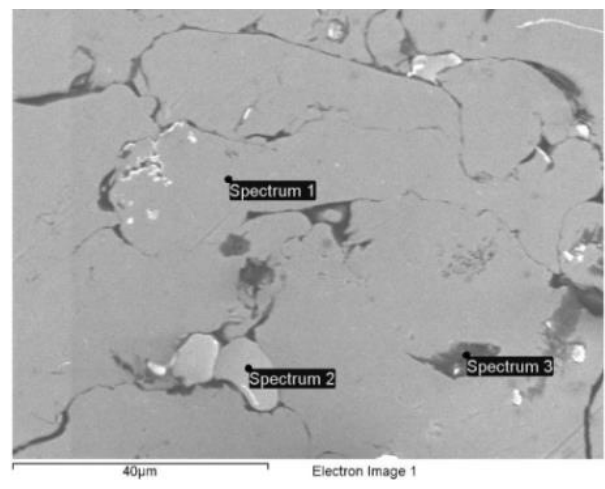

\begin{tabular}{ccc}
\multicolumn{3}{c}{ Sample $4(\mathbf{A l + 0 , 5 \% C )}$} \\
\hline $\begin{array}{c}\text { Designation } \\
\text { of the measurement } \\
\text { area }\end{array}$ & \multicolumn{2}{c}{ Chemical composition, } \\
wt. $\%$ & $\mathbf{A l}$ \\
\hline Spectrum 1 & 4.38 & 95.62 \\
Spectrum 2 & 5.23 & 94.77 \\
Spectrum 3 & 59.76 & 40.24 \\
Standard deviation & 31.73 & 31.73 \\
\hline
\end{tabular}


Fig. 9. Image of the structure of the coating flame-sprayed with aluminum powder with the addition of carburite in the amount of $0.5 \mathrm{wt}$.\% along with the selection of areas for which the chemical composition analysis was performed on a scanning electron microscope

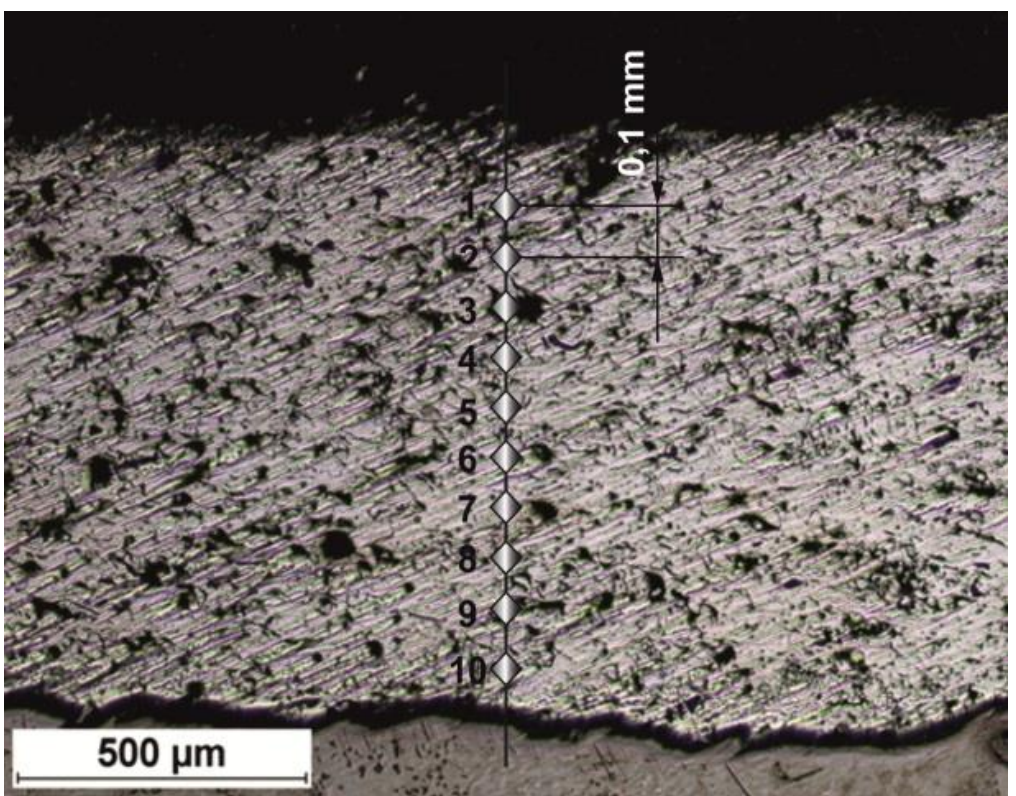

Hardness HV 0.1

\begin{tabular}{ccccccccccccc}
$\begin{array}{c}\text { Designation } \\
\text { of the sample }\end{array}$ & $\mathbf{1}$ & $\mathbf{2}$ & $\mathbf{3}$ & $\mathbf{4}$ & $\mathbf{5}$ & $\mathbf{6}$ & $\mathbf{7}$ & $\mathbf{8}$ & $\mathbf{9}$ & $\mathbf{1 0}$ & $\begin{array}{r}\text { Measurement point } \\
\text { Average }\end{array}$ & $\begin{array}{c}\text { Standard } \\
\text { deviation }\end{array}$ \\
\hline Sample 1 (Al) & 34.9 & 46.2 & 31.8 & 28.3 & 29.6 & 41.0 & 40.5 & 34.2 & 30.3 & 24.1 & 34.1 & 6.39 \\
Sample 2 (Al+0,5\% CNT) & 58.8 & 30.6 & 39.4 & 41.2 & 49.4 & 33.7 & 46.1 & 48.1 & 38.3 & 37.3 & 42.3 & 7.95 \\
Sample 3 (Al+1\% CNT) & 40.1 & 54.4 & 51.0 & 55.3 & 42.1 & 29.2 & 32.1 & 34.5 & 48.1 & 49.5 & 43.6 & 8.95 \\
Sample 4 (Al+0,5\% C) & 27.5 & 40.1 & 34.2 & 41.1 & 31.6 & 34.9 & 31.8 & 33.7 & 36.8 & 41.2 & 35.3 & 4.29 \\
\hline
\end{tabular}

Fig. 10. The results of HV 0.1 hardness measurements on the cross section of coatings flame-sprayed with aluminum powder and powders on aluminum matrix with particles of carbonaceous materials

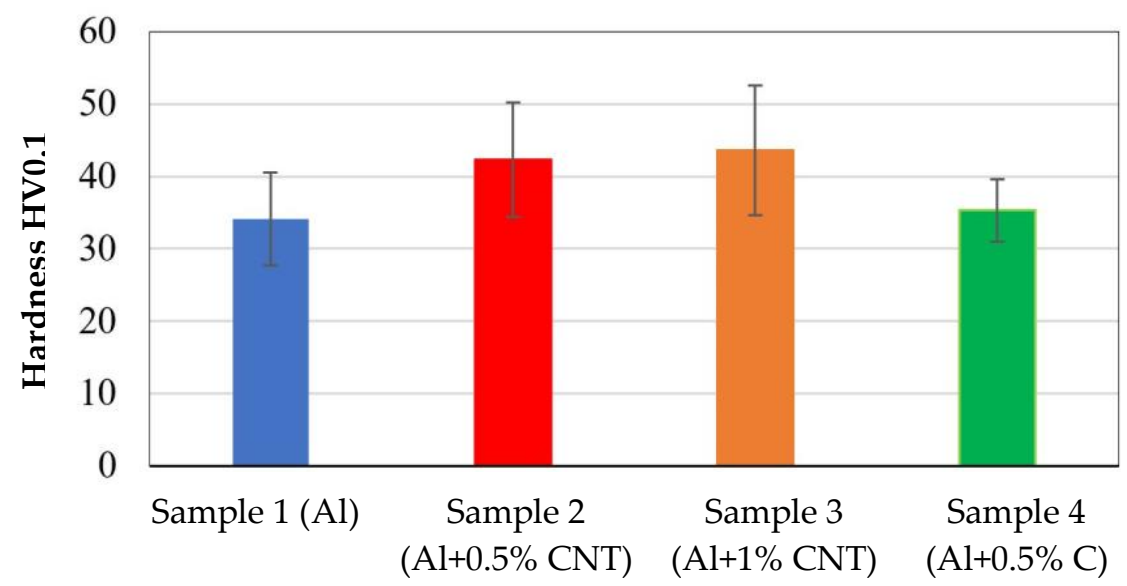

Fig. 11. Comparison of the mean hardness of the cross-section and standard deviation for each tested coating

\section{Results of the tests of coatings resistance to erosive wear}

The results of the relative resistance to erosive wear of coatings flame-sprayed with aluminum powder and powders on aluminum matrix with carbon nanotubes and carburite in the form of coal dust are presented in Table VI and Figure 12. 


\section{Results of the tests of coatings resistance to abrasive wear}

The results of resistance to abrasive wear of the metal-mineral type of flame-sprayed coatings using powders on the aluminum matrix with the addition of carbon nanotubes and carburite were referred to the coating sprayed with aluminum powder without the addition of particles of carbonaceous materials and are shown in Table VII and Figure 13.

Table VI. List of results obtained during the erosion test according to ASTM G76-95

\begin{tabular}{|c|c|c|c|c|c|}
\hline $\begin{array}{c}\text { Angle } \\
\text { of incidence } \\
\text { of the } \\
\text { erodent, 。 }\end{array}$ & $\begin{array}{l}\text { Sample designation/ } \\
\text { Sample number }\end{array}$ & $\begin{array}{c}\text { Mass loss }{ }^{1)}, \\
\mathrm{g}\end{array}$ & $\begin{array}{l}\text { Volume } \\
\text { loss, } \mathbf{m m}^{3}\end{array}$ & $\begin{array}{l}\text { The speed } \\
\text { of erosion, } \\
\text { g/min }\end{array}$ & $\begin{array}{c}\text { Resistance } \\
\text { to erosive wear } \\
\text { acc. to ASTM G76, } \\
0.001 \mathrm{~mm}^{3} / \mathrm{g}\end{array}$ \\
\hline \multirow{4}{*}{90} & Sample 1 (Al)/S1-90 & 0.0054 & 1.985 & 0.00068 & 0.12255 \\
\hline & Sample $2(\mathrm{Al}+0,5 \% \mathrm{CNT}) / \mathrm{S} 2-90$ & 0.0117 & 4.301 & 0.00146 & 0.26552 \\
\hline & Sample $3(\mathrm{Al}+1 \% \mathrm{CNT}) / \mathrm{S} 3-90$ & 0.0071 & 2.610 & 0.00089 & 0.16113 \\
\hline & Sample $4(\mathrm{Al}+0,5 \% \mathrm{C}) / \mathrm{S} 4-90$ & 0.0064 & 2.353 & 0.00080 & 0.14524 \\
\hline \multirow{4}{*}{30} & Sample 1 (Al)/S1-30 & 0.0036 & 1.324 & 0.00045 & 0.08170 \\
\hline & Sample $2(\mathrm{Al}+0,5 \% \mathrm{CNT}) / \mathrm{S} 2-30$ & 0.0066 & 2.426 & 0.00083 & 0.14978 \\
\hline & Sample $3(\mathrm{Al}+1 \% \mathrm{CNT}) / \mathrm{S} 3-30$ & 0.0045 & 1.654 & 0.00056 & 0.10212 \\
\hline & Sample $4(\mathrm{Al}+0,5 \% \mathrm{C}) / \mathrm{S} 4-30$ & 0.0039 & 1.434 & 0.00049 & 0.08851 \\
\hline
\end{tabular}

Notes: 1) average mass loss determined on the basis of three tests; erosion rate, $\mathrm{g} / \mathrm{min}=$ mass loss of the sample, g: exposure time, $\mathrm{min}$; resistance to erosive wear $0.001 \mathrm{~mm}^{3} / \mathrm{g}=$ volume loss of the sample, $\mathrm{mm}^{3}$ : total mass of the erodent used in the test, $\mathrm{g}$; density of the sprayed aluminum coating $2.72 \mathrm{~g} / \mathrm{cm}^{3}$; weight of the used erodent $16.2 \mathrm{~g}$; test time $8 \mathrm{~min}$.

Table VII. List of results obtained during the abrasion resistance test according to ASTM G65

\begin{tabular}{|c|c|c|c|c|c|c|c|}
\hline $\begin{array}{c}\text { Sample } \\
\text { designation }\end{array}$ & $\begin{array}{l}\text { Sample } \\
\text { number }\end{array}$ & $\begin{array}{c}\text { Mass } \\
\text { before } \\
\text { the test, } \\
\mathrm{g}\end{array}$ & $\begin{array}{c}\text { Mass after } \\
\text { the test, } \\
\text { g }\end{array}$ & $\begin{array}{c}\text { Mass loss, } \\
\mathrm{g}\end{array}$ & $\begin{array}{c}\text { Average } \\
\text { mass loss, } \\
\mathrm{g}\end{array}$ & $\begin{array}{c}\text { Volume } \\
\text { loss, } \mathrm{mm}^{3}\end{array}$ & $\begin{array}{c}\text { Relative }^{1)} \\
\text { abrasion } \\
\text { resistance }\end{array}$ \\
\hline \multirow{2}{*}{ Sample 1 (Al) } & S1-1 & 43,9675 & 43,8413 & 0,1262 & \multirow{2}{*}{0,1418} & \multirow{2}{*}{52,1324} & \multirow{2}{*}{1,00} \\
\hline & S1-2 & 42,3855 & 42,2281 & 0,1574 & & & \\
\hline \multirow{2}{*}{$\begin{array}{c}\text { Sample } 2 \\
(\mathrm{Al}+0,5 \% \mathrm{CNT})\end{array}$} & S2-1 & 56,5170 & 56,3924 & 0,1246 & \multirow{2}{*}{0,1286} & \multirow{2}{*}{47,26103} & \multirow{2}{*}{1,10} \\
\hline & S2-2 & 53,8604 & 53,7279 & 0,1325 & & & \\
\hline \multirow{2}{*}{$\begin{array}{c}\text { Sample } 3 \\
(\mathrm{Al}+1 \% \mathrm{CNT})\end{array}$} & S3-1 & 56,9638 & 56,8322 & 0,1316 & \multirow{2}{*}{0,1279} & \multirow{2}{*}{47,0221} & \multirow{2}{*}{1,11} \\
\hline & S3-2 & 57,4587 & 57,3345 & 0,1242 & & & \\
\hline \multirow{2}{*}{$\begin{array}{c}\text { Sample } 4 \\
(\mathrm{Al}+0,5 \% \mathrm{C})\end{array}$} & S4-1 & 59,4423 & 59,3199 & 0,1224 & \multirow{2}{*}{0,1190} & \multirow{2}{*}{43,7500} & \multirow{2}{*}{1,19} \\
\hline & S4-2 & 61,1152 & 60,9996 & 0,1156 & & & \\
\hline
\end{tabular}

Notes: ${ }^{1)}$ relative to the sprayed aluminum coating without carbonaceous materials, the force exerted on the samples during the test was $130 \mathrm{~N}$; volume loss, $\mathrm{mm}^{3}$ = mass loss, g: density, $\mathrm{g} / \mathrm{cm}^{3} \times 1000$; density of the sprayed aluminum coating $2.72 \mathrm{~g} / \mathrm{cm}^{3}$.

\section{Discussion}

Visual and metallographic examinations of coatings on the aluminum matrix of the EN AW 1000 series reinforced with particles of carbon nanotubes Nanocyl NC 7000 in quantities of $0.5 \mathrm{wt} \%$ and $1 \mathrm{wt} . \%$ as well as carburite (elemental carbon) in an amount of $0.5 \mathrm{wt} . \%$, flame-powder sprayed on a non-alloy structural steel of S235J0 grade showed that in the range of optimal process parameters it is possible to make coatings with an acceptable level of quality, characterized by proper adhesion of the coating's material to the substrate, no delamination and uniform coating thickness over the entire surface. The outer surface of the coatings was characterized by a slight roughness, lack of porosity and cracks. During the powder flame spraying process, the carbonaceous materials added to the aluminum powder were not completely oxidized in the acetylene-oxygen flame. Carbon nanotubes (melting point $-4526^{\circ} \mathrm{C}$ ) and carburite (melting point $-3550{ }^{\circ} \mathrm{C}$ ) formed aluminum Al-Cx agglomerates in a gas flame, which due to high volume and lower heat source temperature than other thermal spraying methods (the acetylene-oxygen flame 
temperature equals $3160{ }^{\circ} \mathrm{C}$ ) passed into the coating in large quantities. The Al-Cx agglomerates partially melted and partially plastified in a gas flame collided with the substrate at high speed and thus formed a fragmented coating structure (Fig. 6). Powder flame spraying (PFS) in comparison with, for example, plasma spraying increases the probability of stopping the carburite and carbon nanotubes (CNTs) in the coating of the aluminum matrix-sprayed composite. The presence of carbonaceous materials in powder

\section{Sample designation/Sample number}
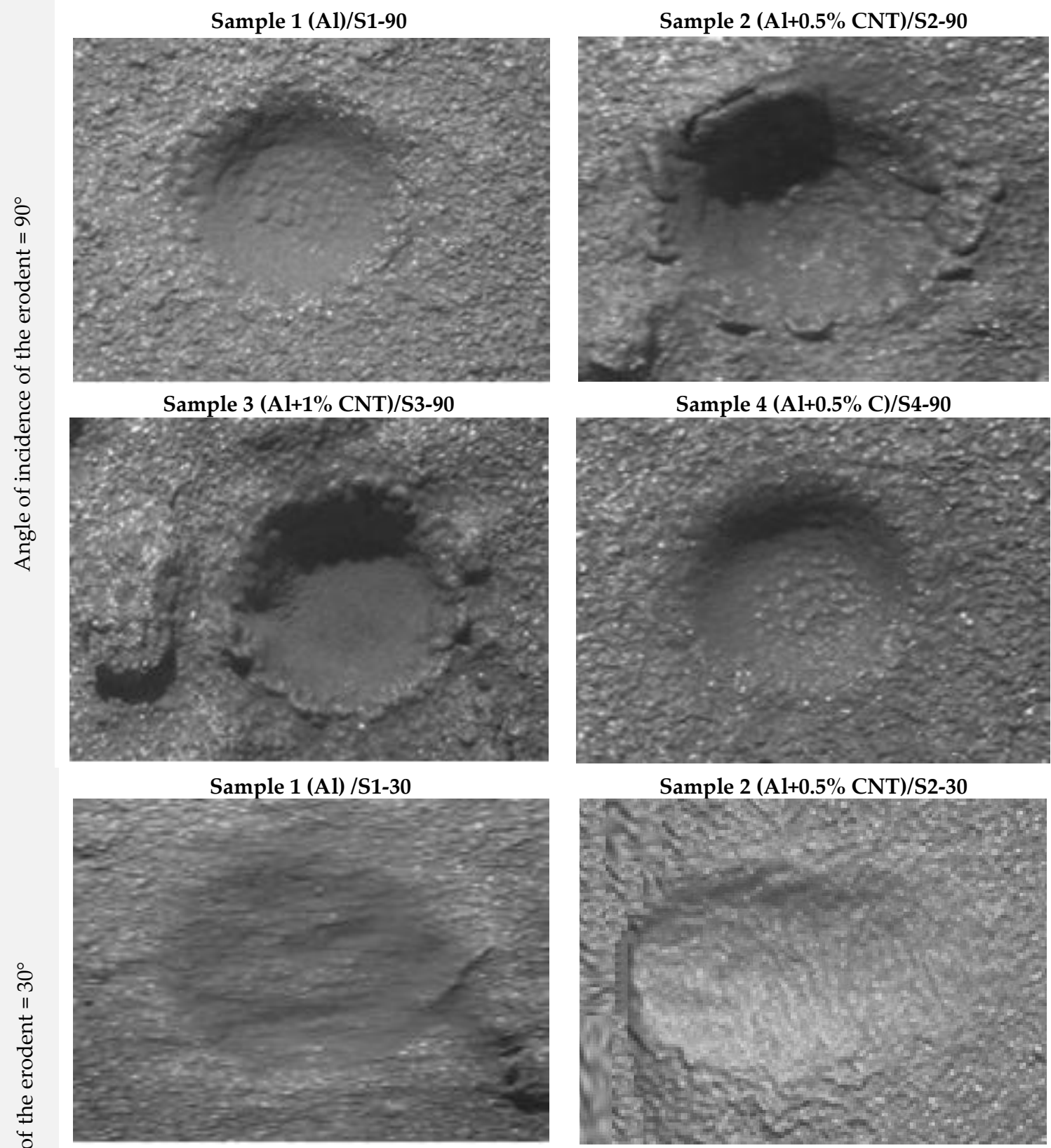

Sample $3(\mathrm{Al}+1 \% \mathrm{CNT}) / \mathrm{S} 3-30$

Sample $4(\mathrm{Al}+0.5 \% \mathrm{C}) / \mathrm{S} 4-30$
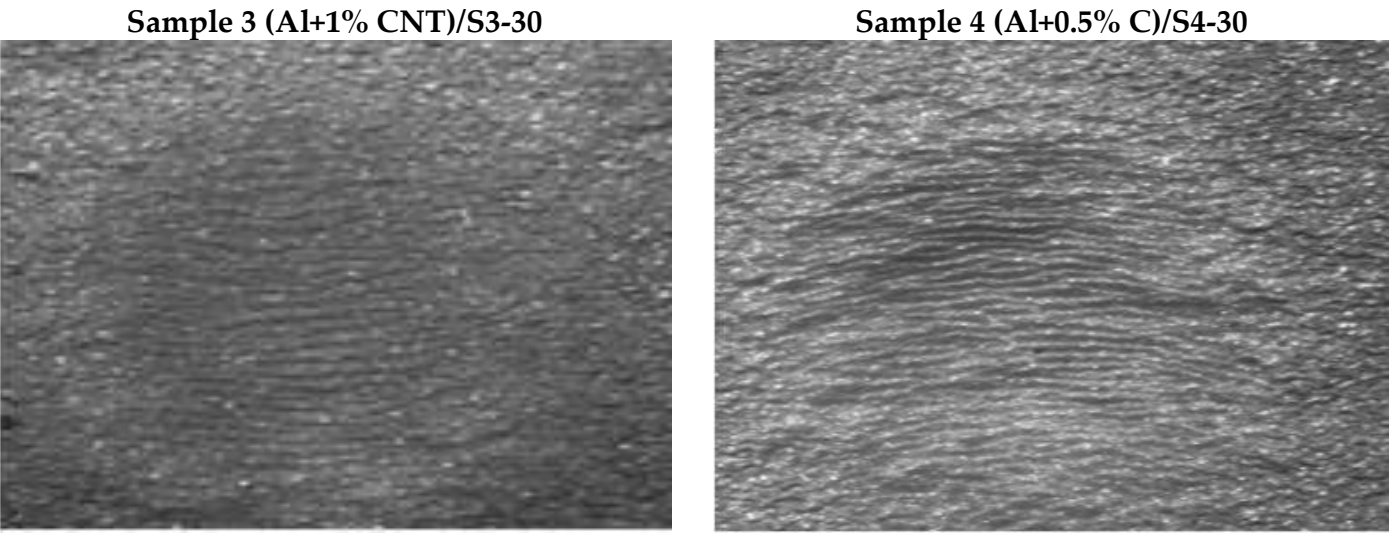
Fig. 12. View of the surfaces of coatings which were flame-sprayed with powders on the aluminum matrix and aluminum reinforced with particles of carbon materials after the erosive wear test, comparison of the erosion effect on the sample surfaces for each of the tested angles of the erodent

\section{Sample designation/Sample number}

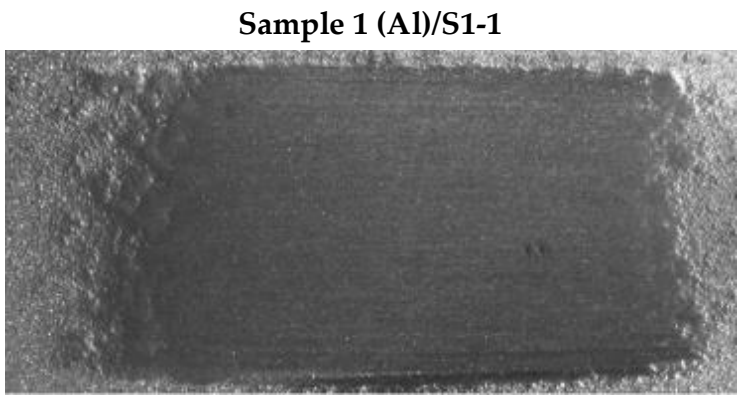

Sample $2(\mathrm{~A} 1+0.5 \% \mathrm{CNT}) / \mathrm{S} 2-1$

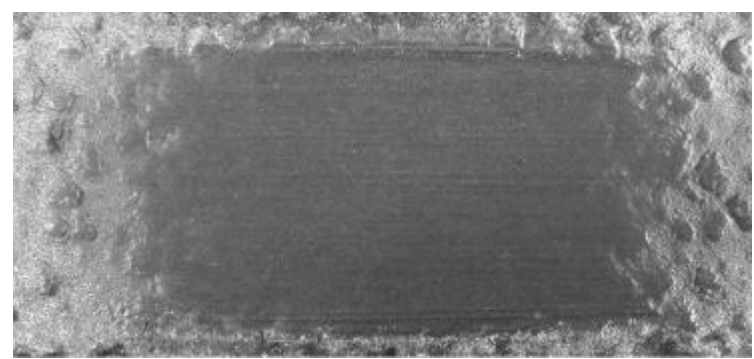

Sample 3 (Al+1\% CNT)/S3-1

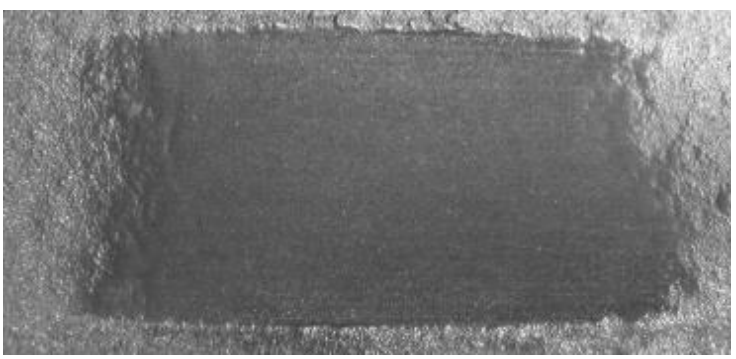

Sample $4(\mathrm{Al}+0.5 \% \mathrm{C}) / \mathrm{S} 4-1$

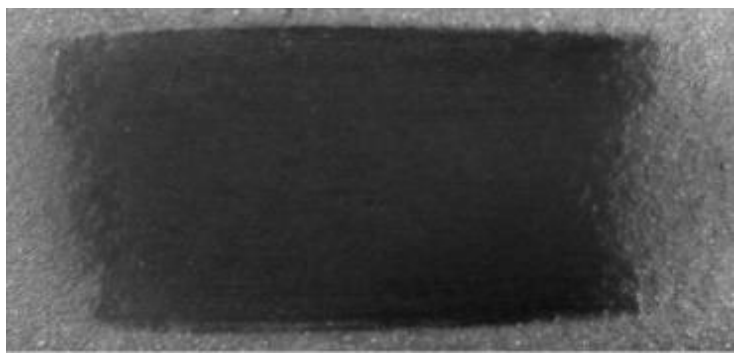

Sample 1 (Al)/S1-2

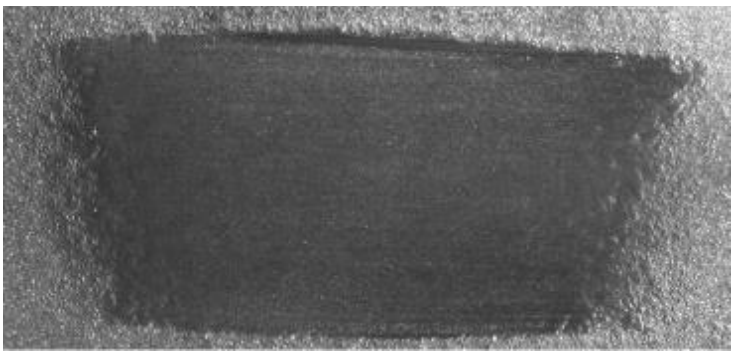

Sample $2(\mathrm{Al}+0.5 \% \mathrm{CNT}) / \mathrm{S} 2-2$

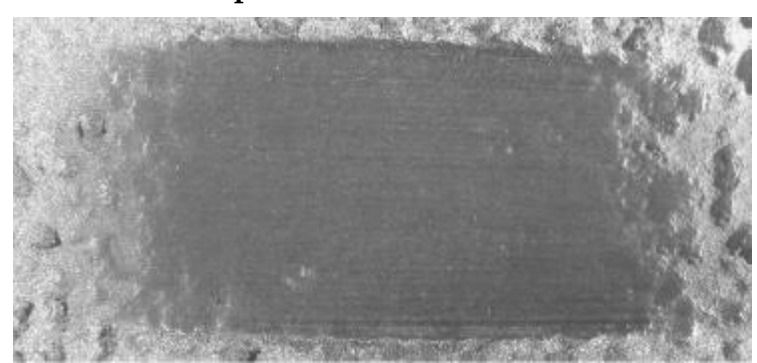

Sample $3(\mathrm{Al}+1 \% \mathrm{CNT}) / \mathrm{S} 3-2$

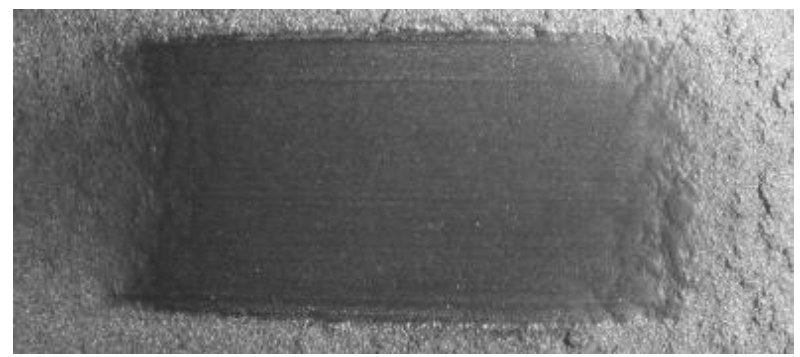

Sample $4(\mathrm{Al}+0.5 \% \mathrm{C}) / \mathrm{S} 4-2$

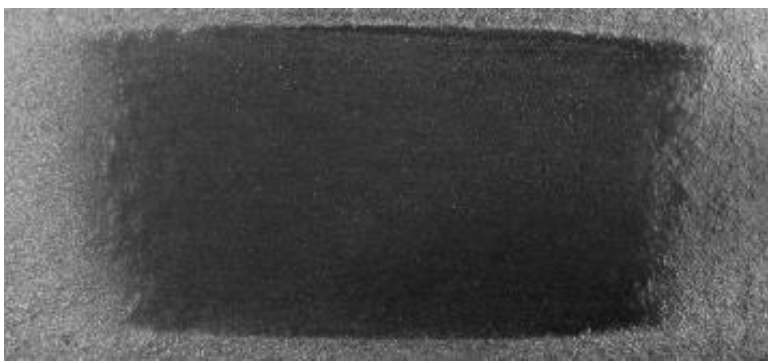

Fig. 13. View of the surfaces of coatings which were flame-sprayed with powders on the aluminum matrix and aluminum reinforced with particles of carbon materials after the abrasive wear test of the metal-mineral type

flame sprayed aluminum coatings is initially confirmed by microscopic metallographic examinations, which revealed the presence of carburite and carbon nanotubes on metallographic specimens, Figure 5 - sample 2. The presence of carbonaceous materials can be observed throughout the cross-section of the coating, also at the outer surface. In the Al-Cx composite coatings, no cracks were found, only the presence of individual voids. Tests carried out on a scanning electron microscope revealed the presence of individual areas composed of small inclusions of carbonaceous materials. In the case of coatings sprayed with aluminum powder with the addition of $0.5 \mathrm{wt}$ \% carbon nanotubes (CNTs) it was found that they can contain areas which can reach up to 20.25 wt.\% of carbon (Fig. 7), and in the case of aluminum coatings containing $1 \%$ of carbon nanotubes (CNT), the carbon content in the investigated areas was up to 33.05 wt.\% (Fig. 8). In contrast, the coating made using aluminum powder with an admixture of $0.5 \mathrm{wt} \%$ carburite contained areas in which the carbon content was almost 3 times higher than in the coating sprayed with aluminum powder 
with the addition of $0.5 \mathrm{wt} . \%$ nanotubes (CNT) (Fig. 9). In the aluminum coating without the addition of carbonaceous materials, the presence of carbon and oxygen was also found (Fig. 6). The proportional small share of carbon in the aluminum coating may be caused by the ease of thermal decomposition of acetylene in the gas flame as well as by the physicochemical properties of unsaturated hydrocarbons [16].

Acetylene dissociates into active carbon atoms (acetylene black, characterized by high purity) and a hydrogen molecule. The proportion of oxygen in the aluminum coating is the result of the oxidation of aluminum particles in the gas flame and the atmosphere. The addition of carbonaceous materials to the aluminum powder causes the carbon to bind the oxygen, hence its presence has not been recorded in composite coatings with an aluminum matrix reinforced with carburite and carbon nanotubes (CNT). Measurement of the hardness of coatings which were flame-sprayed with powders on the aluminum matrix, made on the external surface and cross-section showed that the addition of carbon nanotubes in an amount of $0.5 \mathrm{wt} . \%$ and $1 \mathrm{wt} . \%$, compared to the aluminum reference coating (34.1 HV0.1), increases the average hardness of the surface layer by 8.2 and $9.5 \mathrm{HV} 0.1$, respectively. Admixture of $0.5 \mathrm{wt}$.\% carburite for aluminum powder does not significantly increase the hardness of the coating (Fig. 11). The study of erosive wear resistance has shown that the addition of carbonaceous materials to aluminum powder does not increase the erosive resistance of flame-powder sprayed coatings. Aluminum coatings with the addition of carbon nanotubes, both for large and small angles of incidence of the erodent, showed greater erosive wear than aluminum coatings with carburite particles, and much larger than the aluminum coating without admixtures. It was observed that aluminum coatings flame-sprayed using powders with and without the participation of particles of carbonaceous materials have a greater relative resistance to erosive wear for a smaller incidence angle of the erodent (Table VI). The highest resistance to abrasive wear of the metal-mineral type was characterized by a coating which was flame-sprayed with aluminum powder with an admixture of carburite. The abrasion resistance of this coating was $19 \%$ greater than the resistance of aluminum coating. Aluminum coatings with the addition of carbon nanotubes in an amount of $0.5 \mathrm{wt} . \%$ and $1 \mathrm{wt.} \%$, compared to the aluminum coating, were characterized by a higher relative abrasion resistance by $10 \%$ and $11 \%$, respectively (Table VII). The possible reason for the wear reduction due to abrasion of the surface layer of coatings containing carbonaceous materials could be the increased slippage of ceramic abrasive particles against the metal.

\section{Conclusions}

Analysis of the obtained test results concerning the comparison of the properties of coatings flamesprayed with powders on the aluminum matrix of the EN AW 1000 series reinforced with Nanocyl NC 7000 carbon nanotube particles in an amount of $0.5 \mathrm{wt} . \%$ and $1 \mathrm{wt} . \%$ and carburite (elemental carbon) in an amount of $0.5 \mathrm{wt} . \%$, with the properties of a coating sprayed with aluminum powder without the addition of carbonaceous materials, allows to formulate the following conclusions:

1. There is a possibility of powder flame spraying of high quality coatings, which aluminum matrix contains a small addition of particles of carbonaceous materials.

2. In a coating which was flame-sprayed using aluminum powder with the addition of carburite, areas where the proportion of carbon reached $60 \%$ were found, while in the coating sprayed with aluminum powder with the addition of carbon nanotubes in the amount of $1 \mathrm{wt} . \%$ the area in which the carbon content was approx. $33 \%$ was found.

3. Addition of carbon nanotubes to aluminum powder leads to an increase in the hardness of flamesprayed coatings by approx. $10 \mathrm{HV} 0.1$.

4. Aluminum coatings containing even a small amount of carbon nanotubes or carburite particles show, for both large and small erodent incidence angles, lower resistance to erosive wear than a coating flamesprayed with aluminum powder without any additives.

5. Powder flame sprayed coatings on aluminum matrix reinforced with particles of carbonaceous materials, in the form of carbon nanotubes and carburite, as compared to aluminum coating, show 10 to $20 \%$ more resistance to abrasive wear of metal-mineral type..

\section{References}

1. Kelly A. Composite materials after seventy years. J. Mater. Sci., 2006, 41, 905-912. [CrossRef]

2. Rawal S. Metal-matrix composites for space applications. JOM, 2001, 53(4), 14-17. [CrossRef]

3. Shelly J. S., LeClaire R., Nichols J. Metal-matrix composites for liquid rocket engines. JOM, 2001, 53(4), 18-21. [CrossRef] 
4. Takashi I. Overview of trends in advanced composite research and applications in Japan. Adv. Compos. Mater., 2006, 15(1), 3-37. [CrossRef]

5. Bokobza L. Multiwall carbon nanotube elastomeric composites: A review. Polymer, 2007, 48, 4907-4920. [CrossRef]

6. Curtin W. A., Sheldon B. W. CNT-reinforced ceramics and metals. Mater. Today, 2004, November, 44-49. [CrossRef]

7. White A. A., Best S. M., Kinloch I. A. A Finite Element Study of Crack Behavior for Carbon Nanotube Reinforced Bone Cement. Appl. Ceram. Technol., 2007, 4(1), 1-13. [CrossRef]

8. Bakshi S. R., Singh V., Balani K., Graham McCartney D., Seal S., Agarwal A. Carbon nanotube reinforced aluminum composite coating via cold spraying. Surface \& Coating Technology, 2008, 202, 5162-5169. [CrossRef]

9. Keshri A. K., Balani K., Bakshi S. R., Singh V., Laha T., Seal S., Agarwal A. Structural transformations in carbon nanotubes during thermal spray processing. Surface \& Coating Technology 2009, 203, 2193-2201. [CrossRef]

10. Czupryński A. Properties of $\mathrm{Al}_{2} \mathrm{O}_{3} / \mathrm{TiO}_{2}$ and $\mathrm{ZrO}_{2} / \mathrm{CaO}$ flame-sprayed coatings. Materiali in Tehnologije / Materials and Technology 2017, 51 (1), 205-212. [Hyperlink]

11. Czupryński A., Górka J., Adamiak M., Tomiczek B. Testing of flame sprayed $\mathrm{Al}_{2} \mathrm{O}_{3}$ matrix coatings containing $\mathrm{TiO}_{2}$. Arch. Metal. Mater., 2016, 61(3), 1363-1370. [CrossRef]

12. Czupryński A., Górka J., Adamiak M. Examining properties of arc sprayed nanostructured coatings, Metalurgija, 2016, 55(2), 173-176. [Hyperlink]

13. Chmielewski T., Chmielewski M., Siwek P. Natryskiwanie łukowe powłok Fe-Al. Welding Technology Review 2018, vol. 90(3), 62-67. [CrossRef]

14. Laha T., Agarwal A., McKechnie T., Seal S. Synthesis and characterization of plasma spray formed carbon nanotube reinforced aluminum composite. Mater. Sci. Engineering. A 381, 2004, 249-258. [CrossRef]

15. http://www.sciteex.com.pl/metallisation/.

16. Gaskell D. R. Introduction to the Thermodynamics of Materials, 4th ed., Taylor \& Francis, New York, 2003. [Hyperlink]

(C) 2019 by the authors. Submitted for possible open access publication under the terms and conditions of the Creative Commons Attribution (CC BY) license (http://creativecommons.org/licenses/by/4.0/). 